\title{
Evaluation of forage-based weaning systems in spring-born cross-bred beef calves
}

\author{
John Fredrick Odhiambo ${ }^{1,2}$, Robert Arthur Dailey ${ }^{1}$, Ronnie Helmondollar ${ }^{3}$, \\ James Yeager Pritchard ${ }^{1}$, Phillip Irvin Osborne ${ }^{1 \times}$ \\ ${ }^{1}$ Division of Animal and Nutritional Sciences, West Virginia University, Morgantown, USA; \\ ${ }^{*}$ Corresponding Author: posborne $@$ wvu.edu \\ ${ }^{2}$ Department of Animal Science, University of Wyoming, Laramie, USA \\ ${ }^{3}$ West Virginia University Extension Service, Randolph County Extension Office, Elkins, USA
}

Received 14 January 2013; revised 25 February 2013; accepted 28 March 2013

Copyright (C) 2013 John Fredrick Odhiambo et al. This is an open access article distributed under the Creative Commons Attribution License, which permits unrestricted use, distribution, and reproduction in any medium, provided the original work is properly cited.

\section{ABSTRACT}

Preconditioned calves have greater market value per unit weight than normal-weaned calves. Development of a low cost forage-based preconditioning system allows producers to add value to their calf-crop. This study evaluated calf performance in three forage-based weaning systems; early-weaned calves were backgrounded in legume/grass forage plots and supplemented with commercial preconditioning feed (Treatment 1) or an on-farm corn-mix (Treatment 2). Control (Treatment 3) calves suckled for an additional 45 days. Supplements provided $2.17 \mathrm{~kg}$ TDN/calf/ day. Weights were collected on days 30,0 and 45 with respect to early weaning, from 135 in year 1 and 150 calves in each of the two subsequent years. Effects of treatment, age of dam, sex of calf and their interactions on calf weight gain were analyzed by analysis of covariance using GLM procedures of SAS. Marginal effects of treatment and feed cost were used to evaluate economic feasibility. Sensitivity analyses were evaluated for anticipated market fluctuations in feed costs and calf premiums. Data are reported as least squares means. Calf weight gains differed $(P<0.001)$ among treatments and averaged 1.16, 1.03 and $1.04 \mathrm{~kg} / \mathrm{calf} / \mathrm{day}$ for commercial supplement, corn-mix and controls, respectively. Calves from 2-year-old cows gained less ( $P<0.001)$ weight compared to those from cows 3 - 4 and $\geq 5$ years of age (44.8, 48.9 and $51.5 \mathrm{~kg}$, respectively). Steers calves gained more ( $P<0.001)$ weight compared to heifer calves (51.2 vs. $45.7 \mathrm{~kg}$, respectively). Net returns for corn mix were greater than those for commercial feed $(\$ 1.48$ vs. $\$ 1.35 / \mathrm{kg}$ weight gain, respec- tively). Sensitivity analyses indicated that selection of preconditioning treatment to a large degree was less sensitive to significant changes in market conditions due to the large gap in marginal costs between the two treatments. In conclusion, forage-based weaning systems can be utilized to precondition calves providing an economical means for calf weight gain and profit potential as long as feed costs are held within reasonable limits.

Keywords: Preconditioning; Beef Calves; Early Weaning; Weight Gain

\section{INTRODUCTION}

During periods of drought and fluctuating grain prices, early weaning may become a more viable option than traditional weaning. Early weaning has been shown to impact pregnancy rates and/or percentages of calves born early [1,2]. Weaning at 30 to 45 days [3] or 80 to 150 days postpartum $[2,4,5]$ improved efficiency and was economical [3] when forage quality and/or quantity were inadequate. Early-weaned calves gained more efficiently and yielded greater quality USDA grades than traditionally weaned calves $[6,7]$ at finishing $[8,9]$.

Weaning stress on cows and calves increased when calves were separated at later rather than earlier ages [10]. When weaned calves from small scale producers are commingled, the stress is compounded and results in greater weight loss. Review of previous preconditioning studies in the United States [11] indicated that calves require about 12 days to regain their initial weight after weaning. Back-grounding programs using high-quality pastures and grain supplements minimized weaning weight loss and maximized returns as long as labor and 
feed costs were minimal [12]. Preconditioning calf programs provide added benefits of increased calf weights to cow-calf producers and add value for feeder cattle buyers $[11,13]$.

The present study compared calf performance in three pasture-based weaning systems. The specific hypotheses tested were: 1) can calves be weaned on a high-forage system and supplemented with energy (corn) and achieve the same results as calves on commercial feed; and 2) do growth and economic performances of early-weaned calves differ from those allowed to remain on their dams for an additional 45 days.

\section{MATERIALS AND METHODS}

The West Virginia Quality Assurance "Gold" preconditioning program has established guidelines requiring a 45 -d post-weaning phase with a proper nutritional program and following a specified animal health and management protocol [14]. All procedures were performed with the approval of the West Virginia University Animal Care and Use Committee (ACUC No. 05-1104).

This study was conducted over a 3-month period beginning at first weighing in August and ending at weaning of control calves in October, and was replicated for 3 yrs. Data were collected from 135 (year 1) and 150 (year 2 and year 3 ) spring-born cross-bred Angus and Hereford calves that averaged 6 months of age in August. Calves were weighed 30 days before the experiment and blocked by sex, weight and age of the dam. They were assigned randomly within blocks to three weaning programs: Early weaning plus $45-\mathrm{d}$ preconditioning on pasture and fed either a commercial (Treatment 1; Table 1) or local corn-based preconditioning supplement (Treatment 2; Table 2) or traditionally weaned 45 days later (Control, Treatment 3). Supplements for early weaned calves provided $2.17 \mathrm{~kg}$ TDN and 0.2 and $0.38 \mathrm{~kg}$ protein/calf/d for Treatments 1,2 , respectively. In order to supply the same energy level, commercial supplement was fed at $2.9 \mathrm{~kg} \mathrm{DM} / \mathrm{calf} / \mathrm{d}$ and the local corn mix supplement was fed at $2.5 \mathrm{~kg} \mathrm{DM} /$ calf/d. Forage species present in the pastures were primarily orchard grass (Dactylis glomerata L.), tall fescue (Lolium arundinaceum), and white and red clover (Trifolium repens $\mathrm{L}$. and T. pratense L.), and in less proportion Kentucky bluegrass (Poa pratensis) and timothy grass (Phleum pratense L.).

All calves were weighed and vaccinated at beginning of experiment. Early-weaned calves (Treatments 1,2) were managed together initially in holding pastures for 7 $\mathrm{d}$ before being separated into their final pasture plots. Forty-five days later, all calves were weighed, and the control (Treatment 3) calves were weaned from their dams.

\subsection{Statistical Analysis}

Changes in calf weight at final weaning (d 0 to $d 45)$ were analyzed by analysis of covariance using Generalized Linear Model methods of SAS (SAS Inst., Inc., Cary, $\mathrm{NC}$ ). Linear contrasts were examined for treatment,

Table 1. Composition (DM basis) of the commercial supplement for early-weaned calves in treatment $1^{1}$.

\begin{tabular}{cc}
\hline Component & Amount \\
\hline Active drug ingredients, g/ton & \\
\hline Chlortetracycline & 140 \\
Sulfamethazine & 140 \\
\hline \multicolumn{1}{c}{ Guaranteed analysis ${ }^{2}$} & \\
\hline DM, \% & 86.72 \\
ADF, \% & 20.20 \\
NDF, \% & 38.74 \\
CP, $\%$ & 15.04 \\
CF, $\%$ & 4.13 \\
Ash, $\%$ & 7.69 \\
TDN, \% & 74.68 \\
NEG, Mcal $/ \mathrm{kg}$ & 1.14 \\
NEM, Mcal $/ \mathrm{kg}$ & 1.87 \\
\hline
\end{tabular}

${ }^{1}$ Manufactured by Kalmbach feeds, Inc. (Sandusky, OH) as a $13 \%$ medicated receiving pellet. Supplement fed at $3.18 \mathrm{~kg} \cdot \mathrm{head}^{-1} \cdot \mathrm{d}^{-1}$. As-Fed, to supply $2.89 \mathrm{~kg} \mathrm{DM}$ and $2.17 \mathrm{~kg}$ of TDN and $0.37 \mathrm{~kg}$ of CP. ${ }^{2}$ analysis conducted by Rumen Profiling Laboratory at West Virginia University (Morgantown, WV)

Table 2. Composition (DM basis) of corn-based preconditioning feed for early-weaned calves on treatment $2^{1}$.

\begin{tabular}{cc}
\hline Component & Amount \\
\hline Cracked corn, \% & 96.61 \\
Pasture mineral \# 57809601, \% & 3.36 \\
Aureomycin 50, \% & 0.03 \\
\hline Nutrient composition of cracked corn ${ }^{2}$ \\
\hline DM, \% & 88.0 \\
NDF, \% & 10.80 \\
CP, \% & 9.80 \\
Fat, \% & 4.06 \\
Ash, \% & 1.46 \\
ME, Mcal $/ \mathrm{kg}$ & 3.25 \\
\hline
\end{tabular}

${ }^{1}$ The supplement was fed at $2.86 \mathrm{~kg} \cdot \mathrm{head}^{-1} \cdot \mathrm{d}^{-1}$ As-Fed, to supply $2.50 \mathrm{~kg}$ DM and $2.17 \mathrm{~kg}$ of TDN and $0.2 \mathrm{~kg}$ of CP. ${ }^{2}$ values obtained from NRC 1996, p. $196[23]$ 
calf sex, age of dam and their interactions. A reduced model was used in the final analysis after elimination of non-significant interactions. This final model included the main effects of treatment, age of dam and sex of calf. The covariate term was the change in calf weight from initial weighing in August to early weaning weight in September (day -30 to day 0 ). Residual error was used to test the main effects and their interactions. All tests of significance were conducted at $\mathrm{P}<0.05$ unless otherwise indicated.

\subsection{Economic Analysis}

Treatments were analyzed on the basis of economic feasibility. Marginal effects of early weaning and feed cost were used to evaluate net return per $\mathrm{kg}$ weight gain during the preconditioning period. Marginal values of gain were obtained from [15]. Sensitivity analyses were evaluated in cases where market prices and feed costs were projected to change over time.

\section{RESULTS AND DISCUSSION}

Main effect of treatment was significant $(\mathrm{P}<0.001)$ for calf weight gain from early weaning to normal weaning (Figure 1). On average, calves weaned on commercial supplement gained $1.21 \mathrm{~kg} \cdot \mathrm{BW} \cdot \mathrm{d}^{-1}$ compared to 1.03 and $1.04 \mathrm{~kg} \cdot \mathrm{BW} \cdot \mathrm{d}^{-1}$ for calves weaned on cornbased supplement and normal weaned calves, respectively. Two important conclusions can be made from this observation: 1) preconditioning added net weight value to feeder calves only when they were early-weaned on commercial feed; and 2) calves can be safely earlyweaned on corn-based supplements without any deleterious effect on weight gain. These findings partly agree with the observations of Rayburn et al. [12,15] that calves weaned on high quality pasture and fed high energy supplements such as ground shelled corn or commercial supplements were heavier when marketed. Preshipment weight gains of feeder calves were improved by preconditioning during the ranch weaning period in a previous similar study [16]. Weight gains in earlyweaned calves in relation to those of suckled calves vary from one study to another, because weight gain depends on milking ability of the dams and non-milk nutrients available to the suckling calves $[1,11]$.

Cow age affected calf performance (Figure 2). Calves from 2-yr-old cows gained less $(\mathrm{P}<0.001)$ weight compared to calves from other age groups. These differences could be attributed to low birth weights and milk production in first parity dams. Melton et al. [17] reported average estimated 175-d milk yields of 2, 3 - 4, and $\geq 5$-yr-old to be 553, 666 and $809 \mathrm{~kg}$, respectively. Vargas et al. [18] attributed low weaning weight of calves from first parity dams to the latter's small frame size and low

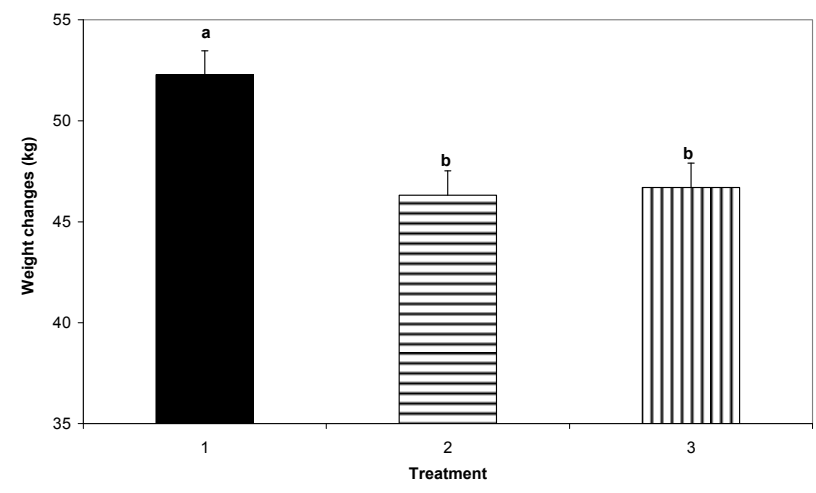

Figure 1. Effect of weaning treatment on calf weight changes from time of early weaning to normal weaning was evaluated in spring-born beef calves. The calves were early-weaned on pasture in September and supplemented with commercial feed (treatment 1, solid bar) or corn-mineral mix (Treatment 2, horizontal bars) for 45-d. Control calves (Treatment 3, vertical bars) were left with their dams for the entire treatment period. ${ }^{a, b}$ least squares mean weights $( \pm \mathrm{SE})$ were differed between treatments $(\mathrm{P}<0.001)$.

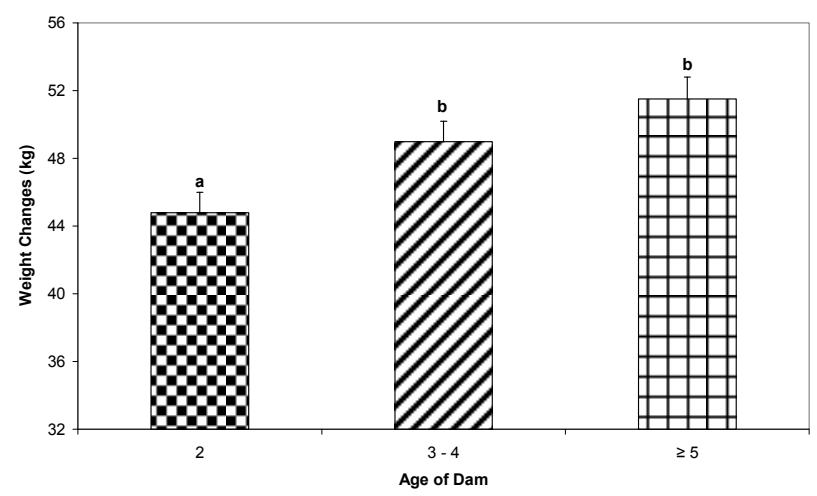

Figure 2. Effect of age of dam on calf weaning weight changes from time of early weaning (September) to normal weaning (October) was evaluated in spring-born beef calves from 2-yrold dams (checkered bars), 3- and 4-yr-old dams (diagonal bars) and dams 5 years of age or older (squares). ${ }^{a, b}$ least squares mean weights $( \pm \mathrm{SE})$ differed between age groups $(\mathrm{P}<0.001)$.

body condition, which affected calf birth weights. Emphasis in this herd of breeding yearling cattle to low-birth weight bulls for calving ease might have impeded growth of their calves.

Six of calf influenced weight gain from normal weaning to final weaning. Steers gained more $(\mathrm{P}<0.001$, data not shown) compared to heifers at final weaning. This is in accordance with biological differences and/or differences in metabolism between males and females. Sex of calf did not $(\mathrm{P}>0.05)$ affect response to treatment in this study. Previous research has documented that steer [2] and heifer $[19,20]$ performances were affected by age at weaning. However, disparities exist in these studies because heifer performances did not mimic that of steers.

Economic pressures to improve production efficiency 
have prompted the beef cattle industry and researchers to evaluate various production systems. Maintaining pasture productivity and calf gain during midsummer is problematic for most cattle producers [6]. Forage yield and quality decline in mid to late summer in most parts of the United States. As a result, body condition and milk production of cows decline. Spring-born calves, therefore, may experience decreased gains at a time when their growth potential is high. Reduced calf gain is due, in part, to reduced milk consumption after the third month of gestation and is exacerbated by cow age [21]. As a result, early weaning had been advocated in two instances: 1) early weaning provided an alternative marketing option for producers to place their early-weaned steers on an accelerated finishing program $[6,22] ; 2)$ and most important, early weaning before start of breeding season improved reproductive performance of cows that were typically at risk of conceiving late in the breeding season or not conceiving at all $[1,2,5]$. Current interest in early weaning is driven by the seasonal price component associated with preconditioning programs that produce healthier and moderate weight feeder calves [13].

\section{Economics of Early Weaning Beef Calves}

Net returns evaluated for the treatments indicated that corn mix was superior to commercial feed (Treatment 2 vs. 1; Table 3), mainly because of the difference in their cost of marginal gain. The mean weight gain from corn mix during the backgrounding period was $46.32 \mathrm{~kg}$. The feed needed to obtain this weight gain was $128.7 \mathrm{~kg}$. Given the average cost of corn mix was $\$ 0.10 / \mathrm{kg}$, the marginal cost of weight gain on corn mix would be $\$ 0.278(128.7 \mathrm{~kg} / 46.32 \mathrm{~kg} \times \$ 0.10)$. Given the marginal value of preconditioned calf is $\$ 1.76 / \mathrm{kg}$ [15], using corn mix returned $\$ 1.48 / \mathrm{kg}(\$ 1.76-\$ 0.278)$. Similarly, the $52.27 \mathrm{~kg}$ gain from commercial feed cost $\$ 0.411 / \mathrm{kg}$ gain

Table 3. Economic analysis of feeding energy supplement on pasture backgrounding programs.

\begin{tabular}{cccc}
\hline \multirow{2}{*}{ Item } & \multicolumn{3}{c}{ Treatment $^{2}$} \\
\cline { 2 - 4 } & 1 & 2 & 3 \\
\hline Mean wt gain, kg & 52.27 & 46.32 & 46.70 \\
Mean cost of wt gain, \$ & 21.45 & 12.89 & - \\
Mean value of wt gain, \$ & 91.87 & 81.58 & - \\
Cost of marginal wt gain, \$ & 0.411 & 0.278 & - \\
Marginal value of wt gain, \$ & 1.76 & 1.76 & - \\
Net return per kg, \$ & 1.35 & 1.48 & - \\
\hline
\end{tabular}

${ }^{1}$ Marginal value of gain for preconditioned calves was $\$ 1.76 / \mathrm{kg}$ obtained from the marginal values reported by Rayburn et al. [15]. ${ }^{2}$ control calves (Treatment 3) were not preconditioned, therefore, did not have any marginal values assigned to their gain. resulting in a net return of $\$ 1.35 / \mathrm{kg}$.

Sensitivity analyses were carried out to evaluate if this advantage provided by corn mix would be sustained if market prices for commodity or calf premiums changed. A $10 \%$ increase in commodity prices and a $10 \%$ decreasein calf premium reduced net returns for both treatments but still maintained the advantage of corn mix (\$1.28 vs. \$1.13; Table 4). A $10 \%$ decline in the cost of commercial feed was compared with a $10 \%$ increase in the cost of corn mix in the last analysis (Table 5). The marginal cost of gain from feeding commercial feed declined to $\$ 0.37$ while that of corn mix increased to $\$$ 0.301 . Consequently, the net returns were still in favor of corn mix ( $\$ 1.46$ vs. $\$ 1.39$, respectively). These analyses indicated that the selection of preconditioning treatment to a large degree is less sensitive to significant changes in market conditions due to the prevailing large gap in return between the treatments.

\section{CONCLUSION}

Pasture backgrounding programs should incorporate well

Table 4. Sensitivity analysis for a $10 \%$ increase in feed cost and a $10 \%$ decline in market value of calf premium.

\begin{tabular}{cccc}
\hline \multirow{2}{*}{ Item } & \multicolumn{3}{c}{ Treatment $^{2}$} \\
\cline { 2 - 4 } & 1 & 2 & 3 \\
\hline Mean wt gain, kg & 52.27 & 46.32 & 46.70 \\
Mean cost of wt gain, $\$$ & 23.61 & 14.16 & --- \\
Mean value of wt gain, $\$$ & 82.48 & 73.23 & --- \\
Cost of marginal wt gain, $\$$ & 0.452 & 0.301 & --- \\
Marginal value of wt gain, $\$$ & 1.58 & 1.58 & --- \\
Net return per kg, $\$$ & 1.13 & 1.28 & --- \\
\hline
\end{tabular}

${ }^{1}$ Based on marginal value of gain for preconditioned calves of $\$ 1.76 / \mathrm{kg}$ reported by Rayburn et al. [15]. ${ }^{2}$ control calves (Treatment 3) were not preconditioned, therefore, did not have any marginal values assigned to their gain.

Table 5. Sensitivity analysis for a $10 \%$ decrease in cost of commercial feed and $10 \%$ increase in cost of corn feed.

\begin{tabular}{cccc}
\hline Item & \multicolumn{3}{c}{ Treatment $^{2}$} \\
\cline { 2 - 4 } & 1 & 2 & 3 \\
\hline Mean wt gain, kg & 52.27 & 46.32 & 46.70 \\
Mean cost of wt gain, $\$$ & 19.31 & 14.16 & --- \\
Mean value of wt gain, $\$$ & 91.87 & 81.58 & --- \\
Cost of marginal wt gain, $\$$ & 0.370 & 0.301 & --- \\
Marginal value of wt gain, $\$$ & 1.76 & 1.76 & --- \\
Net return per kg, $\$$ & 1.39 & 1.46 & --- \\
\hline
\end{tabular}

${ }^{1}$ Marginal value of gain for preconditioned calves was $\$ 1.76 / \mathrm{kg}$ obtained from the marginal values reported by Rayburn et al. [15]. ${ }^{2}$ control calves (treatment 3 ) were not preconditioned, therefore, did not have any marginal values assigned to their gain. 
balanced weaning rations for better calf weight gains. Well managed pasture can provide a clean environment and low-cost feed for weaning calves. Therefore, foragebased weaning systems can successfully be utilized to precondition calves providing an economical means for calf weight gain and profit potential as long as feed costs are held within reasonable limits.

\section{IMPLICATIONS}

An effective nutritional program provides a desirable level of weight gain during the preconditioning period. Feedstuff availability and cost should be considered in developing preconditioning programs. Economical nutritional programs can be designed around farm forages and matching supplementation program to the forage program. Protein is the most expensive constituent of most rations; therefore, supplementation costs in backgrounding programs can be reduced when feeder calves are provided with energy supplements such as corn mix to enable them to utilize high forage crude protein as was demonstrated in this study.

\section{ACKNOWLEDGEMENTS}

The authors acknowledge Mr. Dwayne O'Dell and Mark Pritt of the West Virginia Division of Agriculture Huttonsville Unit for use of their animals and labor, various graduate students who helped with this study, Dr. Yohannes Hailu for assistance with economic analysis, and Dr. Gene Felton for guidance with the nutritional aspects of the study and also for reviewing the manuscript. This work is published with the approval of the director of the WV Agriculture and Forestry Experiment Station as a Scientific Paper No. 3152 from the Division of Animal and Nutritional Sciences. Supported in part by Hatch (WVA-427 and 431) and Northeast Regional (NE-1007) projects and WVU extension service funding.

\section{REFERENCES}

[1] Lusby, K.S., Wettemann, R.P. and Turman, E.J. (1981) Effects of early weaning calves from first-calf heifers on calf and heifer performance. Journal of Animal Science, 53, 1193-1197.

[2] Story, C.E., Rasby, R.J., Clark, R.T. and Milton, C.T. (2000) Age of calf at weaning of spring-calving beef cows and the effect on cow and calf performance and production economics. Journal of Animal Science, 78, 1403-1413.

[3] Houghton, P.L., Lemenager, R.P., Horstman, L.A., Hendrix, K.S. and Moss, G.E. (1990) Effects of body composition, pre- and post-partum energy level and early weaning on reproductive performance of beef cows and preweaning calf gain. Journal of Animal Science, 68, 14381446.

[4] Grimes, J.F. and Turner, B. (1991) Early weaning of fall-born beef calves. I. Preweaning calf and cow performance. Journal of Production Agriculture, 4, 464-468.
[5] Arthington, J.D. and Kalmbacher, R.S. (2003) Effect of early weaning on the performance of three-year-old, firstcalf beef heifers and calves reared in the subtropics. Journal of Animal Science, 81, 1136-1141.

[6] Myers, S.E., Faulkner, D.B., Ireland, F.A. and Parrett, D.F. (1999) Comparison of three weaning ages on cow-calf performance and steer carcass traits. Journal of Animal Science, 77, 323-329.

[7] Wertz, A.E., Berger, L.L., Walker, P.M., Faulkner, D.B., McKeith, F.K. and Rodriguez-Zas, S.L. (2002) Early weaning and postweaning nutritional management affect feedlot performance, carcass merit, and the relationship of 12th rib fat, marbling score, and feed efficiency among Angus and Wagyu heifers. Journal of Animal Science, 80, 28-37.

[8] Fluharty, F.L., Loerch, S.C., Turner, T.B., Moeller, S.J. and Lowe, G.D. (2000) Effects of weaning age and diet on growth and carcass characteristics in steers. Journal of Animal Science, 78, 1759-1767.

[9] Meyer, D.L., Kerley, M.S., Walker, E.L., Keisler, D.H., Pierce, V.L., Schmidt, T.B., Stahl, C.A., Linville, M.L. and Berg, E.P. (2005) Growth rate, body composition, and meat tenderness in early vs. traditionally weaned beef calves. Journal of Animal Science, 83, 2752-2761.

[10] Flower, F.C. and Weary, D.M. (2001) Effects of early separation on the dairy cow and calf: 2 . Separation at 1 day and 2 weeks after birth. Applied Animal Behaviour Science, 70, 275-284.

[11] Cole, N.A. (1985) Preconditioning calves for the feedlot. Veterinary Clinics of North America: Food Animal Practice, 1, 401-410.

[12] Rayburn, E.B., Whetsell, M.A. and Osborne, P.I. (2004) Calf performance related to pasture quality and supplements. WVU Extension Service, Morgantown. http://www.wvu.edu/ agexten/forglvst/calfperform.pdf

[13] Avent, R.K., Ward, E.C. and David, D.L. (2004) Market valuation of preconditioning feeder calves. Journal of Agricultural and Applied Economics, 36, 173-183.

[14] Osborne, P.I. (2000) Wean or sell calves? A management/marketing option for feeder calf producers. West Virginia University Extension Service, Morgantown. http://www.wvu.edu/ agexten/forglvst/weansell.htm

[15] Rayburn, E.B., Whetshell, M.S. and Osborne, P.I. (2006) Calves weaned and backgrounded on pasture respond to pasture nutritive value and supplements. Forage and Grazinglands.

[16] Pritchard, R.H. and Mendez, J.K. (1990) Effects of preconditioning on pre- and post-shipment performance of feeder calves. Journal of Animal Science, 68, 28-34.

[17] Melton, A.A., Riggs, J.K., Nelson, L.A. and Cartwright, T.C. (1967) Milk production, composition and calf gains of Angus, Charolais and Hereford cows. Journal of Animal Science, 26, 804-809.

[18] Vargas, C.A., Olson, T.A., Chase Jr., C.C., Hammond, A.C. and Elzo, M.A. (1999) Influence of frame size and body condition score on performance of Brahman cattle. Journal of Animal Science, 77, 3140-3149.

[19] Richardson, A.T., Martin, T.G. and Hunsley, R.E. (1978) 
Weaning age of Angus heifer calves as a factor influencing calf and cow performance. Journal of Animal Science, 47, 6-14.

[20] Basarab, J.A., Novak, F.S. and Karren, D.B. (1986) Effects of early weaning on calf gain and cow performance and influence of breed, age of dam, and sex of calf. $\mathrm{Ca}$ nadian Journal of Animal Science, 66, 349-360.

[21] Geary, T.W. (2003) Management of young cows for maximum reproductive performance. Proceedings of Beef Improvement Federation.
[22] Myers, S.E., Faulkner, D.B., Ireland, F.A., Berger, L.L. and Parrett, D.F. (1999) Production systems comparing early weaning to normal weaning with or without creep feeding for beef steers. Journal of Animal Science, 77, $300-310$

[23] NRC (1996) Nutrient requirements of beef cattle. 7th Revised Edition, National Academies Press, Washington DC. 